\title{
Analisis Penetapan Harga Pokok Produksi pada Perusahaan Manufaktur di Provinsi Daerah Istimewa Yogyakarta
}

\author{
Dito Aditia Darma Nasution'1 \\ Fakultas Sosial Sains Universitas \\ Iskandar Muda ${ }^{2}$ \\ Pembangunan Panca Budi, Indonesia Universitas Sumatera Utara, Indonesia \\ Email: ditoaditia@dosen.pancabudi.ac.id
}

\begin{abstract}
ABSTRAK
Penelitianini bertujuan untuk menganalisis dan mendeskripsikan bagaimana penetapan harga pokok produksi pada perusahaan manufaktur di Provinsi Daerah Istimewa Yogyakarta. Metode yang digunakan dalam penelitian ini adalah pendekatan kualitatif dengan menggunakan instrumen berupa kuesioner dan wawancara sebagai pendukung yang ditujukan kepada pemilik beberapa perusahaan manufaktur di Provinsi Daerah Istimewa Yogyakarta. Sampel penelitian 52 perusahaan manufaktur yang terdiri dari 33 perusahaan skala menengah dan 19 perusahaan skala besar. Hasil penelitian menunjukkan bahwa perusahaan memiliki lebih dari satu tujuan dalam menetapkan harga pokok produksi. Temuan yang paling penting adalah bahwa faktor utama yang mempengaruhi harga pokok produksi adalah biaya. Ditemukan juga bahwa semua sampel yang diuji percaya bahwa perubahan harga pokok produksi tidak akan efektif dalam meningkatkan volume penjualan.
\end{abstract}

Kata Kunci: PenetapanHarga Pokok Produksi; Harga Berbasis Pasar; Harga Berbasis Biaya; Biaya Produk.

\section{Analysis Cost of Production at Manufacturing Companies in The Special Region of Yogyakarta Province}

\section{ABSTRACT}

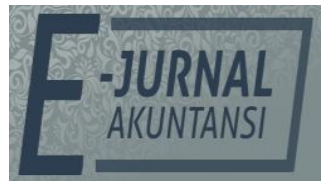

E-JA

e-Jurnal Akuntansi e-ISSN 2302-8556

Vol. 30 No. 6

Denpasar, Juni 2020

Hal.1539-1549

Artikel Masuk:

15 April 2020

Tanggal Diterima: 23 Juni 2020

This study aims to analyze and describe how the determination of the cost of production in manufacturing companies in the Special Region of Yogyakarta Province. The method used in this study is a qualitative approach using instruments in the form of questionnaires and interviews as supporters addressed to the owners of several manufacturing companies in the Special Region of Yogyakarta Province. The research sample of 52 manufacturing companies consisting of 33 medium scale companies and 19 large scale companies. The results showed that the company has more than one goal in setting the cost of production. The most important finding is that the main factor affecting the cost of production is cost. It was also found that all of the samples tested believed that changes in the cost of production would not be effective in increasing sales volume.

Keywords: Implementation of Pricing; Market Based Pricing; Cost Based Pricing; Product Cost.

The Article is Available in: https://ojs.unud.ac.id/index.php/Akuntansi/index 


\section{PENDAHULUAN}

Dewasa ini harga merupakan bagian terpenting dalam bisnis sehingga harus dilakukan penetapan secara rasional dan hati-hati. Penetapan harga merupakan suatu pengambilan keputusan yang sangat penting bagi hampir seluruh perusahaan di Indonesia bahkan dunia. Setiap perusahaan, apakah itu sebuah perusahaan manufaktur atau jasa harus menetapkan harga mereka masingmasing. Desai et al (2016) menyebutkan bahwa perusahaan manufaktur harus menetapkan harga untuk produk yang mereka produksi. Sebagai contoh perusahaan merchandise menetapkan harga pokok produksi untuk barangnya dan perusahaan jasa menetapkan harga pokok produksi yang disebut cost of revenue (COR) untuk layanan mereka. Droste \& Bartkowski (2018) menyatakan bahwa keputusan penetapan harga pokok produksi biasanya dibuat dalam waktu singkat. Ini berarti bahwa harga pokok produksi ditetapkan pada periode maksimal satu tahun. Sunarni \& Ambarriani (2019) menyatakan bahwa dalam pasar bisnis yang sangat kompetitif, informasi adalah faktor yang paling penting untuk kelangsungan bisnis. Salah satu informasi akuntansi yang sangat dibutuhkan adalah informasi akuntansi manajemen.

Tujuan utama dari akuntansi manajemen dalam organisasi adalah untuk membantu manajemen melakukan fungsi mereka dalam mengumpulkan, memproses, dan mengkomunikasikan informasi dengan memberikan informasi, termasuk informasi mengenai harga pokok produksi. Dari sudut pandang akuntansi manajemen, keputusan manajerial diklasifikasikan menjadi dua jenis keputusan yaitu keputusan manajerial jangka pendek dan keputusan manajerial jangka panjang. Umumnya, harga pokok produksi akan disesuaikan karena adanya perubahan harga dalam sumber daya ekonomi atau inflasi. Implementasi harga pokok produksi merupakan salah satu keputusan manajerial yang paling penting. Implementasi harga pokok produksi tidak hanya mempengaruhi pendapatan akan tetapi juga dapat memberikan konsekuensi penting yang lain. Jika implementasi harga pokok produksi dianggap terlalu rendah, maka penjualan kemungkinan besar akan meningkat, namun perusahaan tidak akan mampu menutupi biaya pembuatan produk. Sebaliknya jika implementasi harga pokok produksi terlalu tinggi, maka biaya pembuatan produk akan terjaga, namun penjualan akan mengalami penurunan (Lee et al, 2015).

Penetapan harga pokok produksi adalah proses keputusan untuk menetapkan harga suatu produk (Merkusiwati \& Damayanthi, 2020). Penetapan harga pokok produksi berbeda dari kebijakan harga pokok produksi (Pradnyadevi \& Suardikha, 2020). Dugan et al (2017) menyatakan bahwa kebijakan harga pokok produksi adalah pernyataan sikap manajemen terhadap keputusan harga pokok produksi. Biasanya, kebijakan harga pokok produksi harus ditekankan untuk memaksimalkan keuntungan secara konsisten pada perusahaan. Dalam jangka panjang, harga pokok produksi harus cukup untuk menutup seluruh biaya perusahaan dan menghasilkan keuntungan yang memuaskan pada perusahaan (Setiawan \& Putra, 2019). Dengan menutup semua biaya dan memberikan keuntungan yang memuaskan, suatu perusahaan dapat mempertahankan dan meningkatkan posisinya dalam persaingan bisnis. Dalam jangka pendek, harga pokok produksi setidaknya harus mencakup biaya tambahan dalam memberikan produk kepada pelanggan. Bijakši et al (2017) 
menyatakan bahwa kebijakan harga pokok produksi adalah cara yang tepat untuk mengatasi situasi harga, sedangkan dalam penetapan harga pokok produksi dapat berubah sebagai pendukung atau bersifat penetapan adhoc.

Perspektif teori ekonomi menyatakan bahwa harga harus mempertimbangkan berbagai struktur pasar yang kompetitif, monopoli dan oligopoli, fungsi permintaan dan penawaran dan juga biaya (Yan $\mathrm{Hu} \& \mathrm{Mao}$, 2017). Namun, ada beberapa keterbatasan dalam perspektif teori ekonomi pada penentuan harga pokok produksi yang tidak mudah untuk mengidentifikasi dan merumuskan struktur pasar, pasokan dan permintaan. Dari perspektif akuntansi manajerial, keputusan harga pokok produksi jauh lebih sederhana dan lebih praktis (Yiming et al, 2016). Harga pokok produksi yang baik adalah harga yang cukup untuk menutup semua biaya dan menghasilkan keuntungan yang memuaskan kepada perusahaan (Pohland \& Kesgin, 2018).

Tujuan dari penelitian ini adalah untuk menyelidiki keputusan harga pokok produksi (bukan kebijakan harga) pada perusahaan skala menengah dan perusahaan skala besar dari perspektif akuntansi manajemen serta membandingkan implementasi diantara mereka, khususnya peran informasi biaya produk dalam pengambilan keputusan. Biondi \& Giannoccolo (2015) menyatakan bahwa perusahaan skala besar mampu mengeluarkan biaya tambahan berupa iklan untuk meningkatkan persepsi pelanggan atas produknya, dan banyak perusahaan skala kecil tidak mampu untuk melakukannya. Akibatnya, perusahaan skala besar mungkin memiliki keuntungan biaya atas perusahaan skala kecil dikarenakan kemampuan untuk menetapkan harga pokok produksi yang lebih tinggi. Dalam menetapkan harga pokok produksi mereka, perusahaan skala besar akan lebih berani jika dibandingkan dengan perusahaan skala kecil. Luca et al (2020) menyatakan bahwa operasi perusahaan skala kecil dalam industri dimana harga pokok produksi ditetapkan oleh pemimpin pasar yang dominan akan memiliki sedikit pengaruh atas harga produk atau jasa. Di perusahaan tersebut, informasi biaya diharapkan akan dianggap sebagai faktor utama dalam menetapkan harga pokok produksi.

Lin (2019) menyimpulkan bahwa persaingan akan menjadi faktor utama dalam harga pokok produksi usaha perusahaan skala kecil, mungkin lebih mudah untuk menggambarkan bagaimana harga pokok produksi ditetapkan di perusahaan skala kecil daripada di perusahaan-perusahaan skala besar. Meskipun mungkin harga pokok produksi perusahaan skala kecil kurang fleksibel daripada harga pokok produksi perusahaan skala besar. Sebuah perusahaan yang menjual produk mereka di luar negeri atau sebuah perusahan ekspor memiliki pasar yang lebih kompetitif jika dibandingkan perusahaan yang menjual secara lokal atau non ekspor (Anton \& Costache, 2015). Faktor pasar juga memiliki pengaruh lebih daripada informasi biaya produk dalam pengambilan keputusan harga pokok produksi. Peran informasi biaya produk akan menjadi kurang penting bagi perusahaan non ekspor akan tetapi menjadi keharusan dan sangat penting bagi perusahaan ekspor.

Penelitian ini mencoba untuk mengeksplorasi apakah tujuan, faktor-faktor yang mempengaruhi perubahan harga pokok produksi dan peran biaya antara perusahaan ekspor dan perusahaan non ekspor. Tujuan utama dari penelitian ini 
adalah untuk menemukan faktor-faktor yang digunakan oleh perusahaan manufaktur skala besar dalam menetapkan harga pokok produksi mereka di Provinsi Daerah Istimewa Yogyakarta.

\section{METODE PENELITIAN}

Penelitian ini menggunakan data primer yang dikumpulkan menggunakan kuesioner. Kuesioner penelitian dikembangkan berdasarkan penelitian yang dilakukan oleh (Aubert et al, 2019). Kuesioner yang dibagi menjadi dua bagian. Bagian pertama bertanya tentang karakteristik perusahaan. Bagian kedua terdiri dari sepuluh pertanyaan tentang bagaimana harga pokok produksi ditetapkan oleh perusahaan. Ada 6 faktor penting yang digunakan untuk menggambarkan keputusan harga pokok produksi yaitu obyektivitas, pesaing, biaya, perubahan harga, volume penjualan dan regulasi. Para responden diberikan daftar 10 item dari faktor harga dan diminta untuk menunjukkan dengan menggunakan skala 3 poin ( $1=$ tidak setuju, 2-netral, dan $3=$ setuju), seberapa penting mereka menganggap masing-masing item dalam keputusan harga pokok produksi. Adapun kuesioner yang digunakan yaitu sebagai berikut.

\begin{tabular}{ll}
\hline \multicolumn{1}{c}{ Faktor } & \multicolumn{1}{c}{ Uraian } \\
\hline Tujuan Harga Pokok Produksi & Memaksimalkan Keuntungan \\
& Perusahaan. \\
& Mencapai Target Profit. \\
& Mempertahankan Pangsa Pasar. \\
& Menutupi Semua Biaya Variabel. \\
Unsur Yang Mempengaruhi Penetapan & Biaya Pokok. \\
Harga Pokok Produksi & Biaya Overhead Pabrik. \\
& Harga Pesaing. \\
& Pelangganyang Bersediauntuk \\
& Membayar. \\
& KelompokPelanggan \\
& Biaya Pokok. \\
& Biaya Overhead Pabrik. \\
& Harga Pesaing. \\
& Pelangganyang Bersedia untuk \\
& Membayar. \\
Faktor Yang Mempengaruhi Perubahan & Biaya Pokok. \\
Harga Pokok Produksi & Biaya Overhead Pabrik. \\
& Harga Pesaing. \\
Alat untuk $\quad$ Meningkatkan $\quad$ Volume & Pelanggan. \\
Penjualan & Iklan di Media Radio. \\
& Iklan di Media Online. \\
& Iklan di Media Televisi. \\
& Penurunan Harga Jual. \\
& Pemerintah Pusat. \\
& Pemerintah Daerah. \\
\hline &
\end{tabular}

Sumber: Data Penelitian, 2020 
Kuesioner penelitian ini disampaikan secara acak kepada pemilik dari beberapa perusahaan manufaktur di Provinsi Daerah Istimewa Yogyakarta. Secara garis besar kuesioner memberikan informasi awal dari jenis informasi yang akan dikumpulkan untuk selanjutnya dilengkapi dengan teknik wawancara. Ghozali (2016) menyatakan bahwa tujuan dari kuesioner adalah untuk meringkas waktu dalam wawancara dan juga untuk memastikan bahwa orang yang tepat siap untuk diwawancarai. Sebanyak 52 perusahaan manufaktur yang terletak di Provinsi Daerah Istimewa Yogyakarta setuju dan siap untuk diwawancarai dalam penelitian ini. Wawancara mendalam yang dilakukan bertujuan untuk mengumpulkan informasi yang dibutuhkan dalam penelitian ini (Maxwell \& Reybold, 2015).

Populasi merujuk pada seluruh kelompok orang, peristiwa, atau hal-hal menarik yang akan diteliti (Sugiyono, 2016). Populasi pada penelitian ini adalah perusahaan manufaktur di Provinsi Daerah Istimewa Yogyakarta, Indonesia. Sampel penelitian dipilih dengan menggunakan purposive sampling. Menurut Hinrichs et al (2017) purposive sampling adalah metode pemilihan sampel yang terbatas dengan orang-orang tertentu yang dapat memberikan informasi yang diinginkan. Ada dua jenis purposive sampling yaitu judge sampling dan quota sampling. Sebuah sampel acak sederhana adalah bagian dari populasi statistik dimana setiap setiap anggota memiliki probabilitas yang sama dipilih (Minakshi, 2017). Hal ini juga dapat dinyatakan bahwa sampel acak adalah contoh yang dipilih secara acak. Penelitian ini menggunakan judge sampling dan karakteristik adalah jumlah karyawan perusahaan harus lebih dari 20 karyawan.

Sampel terdiri dari 63,46\% (33 perusahaan) adalah perusahaan skala menengah dan 36,54\% (19 perusahaan) adalah perusahaan skala besar. Menurut Badan Pusat Statistik Republik Indonesia, sebuah perusahaan dapat diklasifikasikan sebagai perusahaan skala mikro jika memiliki kurang dari 3 karyawan, skala kecil jika memiliki 3-19 karyawan, skala menengah jika memiliki 20-99 karyawan dan perusahaan skala besar jika memiliki lebih dari 100 karyawan. Penelitian ini menggunakan klasifikasi ini karena sangat mudah untuk mendapatkan informasi tentang jumlah karyawan daripada informasi tentang pendapatan penjualan atau keuntungan per tahun. Semua perusahaan yang berpartisipasi bisa mengidentifikasi jumlah karyawan mereka dengan mudah dan akurat serta mereka tidak segan untuk berbagi informasi tersebut kepada pihak eksternal. Klasifikasi berikutnya dari sampel didasarkan pada wilayah penjualan yaitu $38,46 \%$ dari sampel (22 perusahaan) menjual produk mereka ke negara-negara lain (perusahaan ekspor), sedangkan 61,54\% (30 perusahaan) menjual produk mereka secara lokal (perusahaan non ekspor). dekskripsi sampel dapat dijelaskan pada Tabel 2.

Analisis data dilakukan dengan menggunakan statistik deskriptif dengan membandingkan persentase perusahaan skala menengah dengan perusahaan skala besar dan perusahaan ekspor serta perusahaan non ekspor untuk setiap pertanyaan penelitian (McNabb, 2017). 
Tabel 2. Dekskripsi Sampel

\begin{tabular}{lll}
\hline & $\mathrm{N}=52$ & $\%$ \\
\hline Wilayah Penjualan & & \\
1. Ekspor & 22 & $38,46 \%$ \\
2. Non Ekspor & 30 & $61,54 \%$ \\
Jumlah Karyawan & & \\
1. 20-99 (Skala Menengah) & 33 & $63,46 \%$ \\
2. > = 100 (Skala Besar) & 19 & $36,54 \%$ \\
Evaluasi Harga & & \\
1. Kurang dari 1 bulan & 8 & $15,4 \%$ \\
2. Antara 2-3 bulan & 12 & $23,1 \%$ \\
3. Antara 4-5 bulan & 2 & $38 \%$ \\
4. Antara 6-7 bulan & 30 & $57,7 \%$ \\
5. Lebih dari 7 bulan & 0 & 0 \\
\hline
\end{tabular}

Sumber: Data Penelitian, 2020

\section{HASIL DAN PEMBAHASAN}

Analisis data mencerminkan jawaban responden mengenai praktek harga di perusahaan mereka. Ada enam pertanyaan dalam penelitian ini yaitu (1) apa tujuan dari harga pokok produksi, (2) apa peran dari pesaing, (3) apa peran dari biaya, (4) kapan waktu untuk melakukan perubahan harga pokok produksi, (5) apa yang dilakukan perusahaan untuk meningkatkan volume penjualan dan (6) apa peran dari regulasi pemerintah. Analisis ini didasarkan pada responden yang memberikan sikap dari jumlah yang menjawab setuju pada setiap pertanyaan. Seperti yang dapat dilihat pada tabel 2, mayoritas sebagian besar responden menjawab bahwa ada dua tujuan penetapan harga pokok produksi, yang pertama adalah mencapai target profit (80,9\%), yang mana dapat mewakili perspektif jangka pendek dan mempertahankan pangsa pasar $(86,5 \%)$, yang mana lebih kepada mewakili perspektif jangka panjang.

Tabel 3. Tujuan Harga Pokok Produksi

\begin{tabular}{|c|c|c|c|c|c|}
\hline \multirow[b]{2}{*}{ Deskripsi } & \multirow[b]{2}{*}{$\%$} & \multicolumn{2}{|c|}{ Skala Perusahaan } & \multicolumn{2}{|c|}{ Area Penjualan } \\
\hline & & Menengah & Besar & Ekspor & $\begin{array}{l}\text { Non } \\
\text { Ekspor }\end{array}$ \\
\hline $\begin{array}{l}\text { Memaksimalkan } \\
\text { Keuntungan Perusahaan }\end{array}$ & $59,6 \%$ & $48,5 \%$ & $78,9 \%$ & $59,1 \%$ & $60,0 \%$ \\
\hline Mencapai Target Profit & $80,8 \%$ & $69,7 \%$ & $100 \%$ & $81,8 \%$ & $80,0 \%$ \\
\hline $\begin{array}{l}\text { Mempertahankan Pangsa } \\
\text { Pasar }\end{array}$ & $86,5 \%$ & $87,9 \%$ & $84,2 \%$ & $77,3 \%$ & $93,3 \%$ \\
\hline $\begin{array}{l}\text { Menutupi Semua Biaya } \\
\text { Variabel }\end{array}$ & $26,9 \%$ & $30,3 \%$ & $28,6 \%$ & $18,2 \%$ & $33,3 \%$ \\
\hline
\end{tabular}

Sumber: Data Penelitian, 2020

Hasil ini sejalan dengan penelitian yang dilakukan oleh Sunarni \& Ambarriani (2019) yang menyatakan secara umum tujuan utama dari perusahaan dalam menetapkan harga pokok produksi adalah untuk menjaga dan memaksimalkan keuntungan. Hasil ini juga menjelaskan bahwa tujuan dari harga pokok produksi tidak hanya satu tujuan. Ternyata perusahaan mengejar beberapa tujuan dalam menetapkan harga pokok produksi mereka. Tabel 3 menunjukkan bahwa tujuan penetapan harga pokok produksi tidak berbeda. 
Meskipun yang paling penting untuk perusahaan skala menengah adalah untuk mempertahankan pangsa pasar, yang sifatnya adalah perspektif jangka panjang.

Ada beberapa elemen yang dianggap sebagai faktor yang paling penting dalam menetapkan harga pokok produksi. Penelitian ini hanya mengidentifikasi 5 unsur yaitu biaya pokok, biaya overhead pabrik, harga pesaing, pelanggan yang bersedia untuk membayar dan kelompok pelanggan. Seperti yang disajikan pada tabel 3 yang paling responsif dalam memilih biaya sebagai unsur paling penting dalam menetapkan harga pokok produksi mereka. Kondisi ini mirip dengan semua jenis organisasi apakah itu perusahaan skala menengah ataupun perusahaan skala besar serta untuk perusahaan ekspor maupun non ekspor. Menariknya, ditemukan bahwa biaya memiliki pengaruh yang paling berpengaruh dalam menetapkan harga pokok produksi dengan 92,3\% dari responden mengatakan bahwa biaya pokok adalah elemen yang penting dalam penetapan harga pokok produksi dan $76,9 \%$ mengatakan bahwa biaya overhead pabrik juga penting dalam penetapan harga pokok produksi. Biaya pokok mewakili total biaya produksi pada perusahaan manufaktur. Ini terdiri dari bahan langsung, tenaga kerja langsung dan overhead pabrik. Dari perspektif perilaku biaya, bahan langsung dan tenaga kerja langsung adalah biaya variabel. Sedangkan pada biaya overhead pabrik dapat di klasifikasikan dalam biaya variabel dan juga biaya tetap. Kesulitan dalam mengendalikan dan memperkirakan biaya juga berbeda. Bisa dikatakan bahwa keakuratan perhitungan biaya produk akan menentukan kualitas dari biaya pokok.

Tabel 4 juga menjelaskan bahwa hanya 51,9\% responden yang menjawab bahwa harga pesaing adalah elemen penting dalam penetapan harga pokok produksi. Hasil ini menjelaskan bahwa responden merasa faktor eksternal (pesaing dan pelanggan) kurang penting jika dibandingkan dengan biaya dalam penetapan harga pokok produksi. Hal ini dikarenakan lebih sulit bagi perusahaan untuk mengontrol dan memprediksi faktor eksternal daripada faktor internal. Hasil yang menarik juga ditemukan pada perusahaan ekspor dan perusahaan non ekspor. Untuk perusahaan ekspor pelanggan yang bersedia untuk membayar dianggap lebih penting daripada harga pesaing akan tetapi untuk perusahaan non ekspor situasinya adalah sebaliknya.

Tabel 4. Unsur Yang Mempengaruhi Penetapan Harga Pokok Produksi

\begin{tabular}{llllll}
\hline \multirow{2}{*}{ Deskripsi } & \multicolumn{3}{c}{ Skala Perusahaan } & \multicolumn{2}{c}{ Area Penjualan } \\
& & Menengah & Besar & Ekspor & $\begin{array}{l}\text { Non } \\
\text { Ekspor }\end{array}$ \\
\hline Biaya Pokok & $92,3 \%$ & $90,9 \%$ & $94,7 \%$ & $90,9 \%$ & $93,3 \%$ \\
Biaya Overhead Pabrik & $76,9 \%$ & $81,8 \%$ & $68,4 \%$ & $68,2 \%$ & $83,3 \%$ \\
$\begin{array}{l}\text { Harga Pesaing } \\
\text { Pelanggan yang }\end{array}$ & $51,9 \%$ & $51,5 \%$ & $56,2 \%$ & $40,9 \%$ & $60,0 \%$ \\
$\begin{array}{l}\text { untuk Membayar } \\
\text { Kelompok Pelanggan }\end{array}$ & $44,2 \%$ & $41,4 \%$ & $47,4 \%$ & $50,0 \%$ & $40,0 \%$ \\
Sumber:Data Penelitian , 2020 & $38,5 \%$ & $39,4 \%$ & $36,8 \%$ & $36,4 \%$ & $40,0 \%$ \\
\hline
\end{tabular}

Secara teoritis, penetapan harga pokok produksi merupakan keputusan jangka pendek yang akan dievaluasi dalam waktu kurang dari 12 bulan atau satu tahun. Responden dianggap mengubah harga pokok produksi jika ada perubahan dalam satu atau lebih faktor. Faktor yang paling signifikan mengarah 
ke perubahan harga terhadap biaya pokok yaitu dengan 94,2 persen responden memilih opsi ini. Hasil ini konsisten dengan jawaban sebelumnya bahwa didapati biaya merupakan faktor yang paling penting dalam harga pokok produksi. Biaya pokok penjualan merupakan biaya produksi untuk produk yang dijual yang terdiri dari bahan langsung, tenaga kerja langsung dan biaya overhead pabrik. Semua jenis perusahaan apakah skala menengah maupun skala besar atau perusahaan ekspor maupun perusahaan non ekspor cenderung untuk menjawab faktor yang sama. Ditemukan juga bahwa pelanggan hanya memiliki pengaruh setidaknya pada memulai perubahan harga pokok produksi dengan persentase hanya sebesar $50 \%$. Di pasar global yang kompetitif, pelanggan adalah faktor yang paling penting yang akan menentukan eksistensi perusahaan. Jika produk perusahaan dipilih oleh pelanggan, perusahaan akan mampu mempertahankan posisi di pasar, namun jika pelanggan tidak memilih produk perusahaan, perusahaan akan mendapatkan masalah.

Tabel 5. Faktor Yang Mempengaruhi Perubahan Harga Pokok Produksi

\begin{tabular}{llllll}
\hline \multirow{2}{*}{ Deskripsi } & \multicolumn{3}{c}{ Skala Perusahaan } & \multicolumn{2}{c}{ Area Penjualan } \\
& & Menengah & Besar & Ekspor & $\begin{array}{l}\text { Non } \\
\text { Ekspor }\end{array}$ \\
\hline Biaya Pokok & $94,2 \%$ & $93,9 \%$ & $94,7 \%$ & $86,4 \%$ & $100 \%$ \\
Biaya Overhead Pabrik & $78,8 \%$ & $90,9 \%$ & $57,9 \%$ & $68,2 \%$ & $66,7 \%$ \\
Harga Pesaing & $55,8 \%$ & $57,6 \%$ & $52,6 \%$ & $45,5 \%$ & $63,3 \%$ \\
Pelanggan & $50,0 \%$ & $54,5 \%$ & $42,1 \%$ & $45,5 \%$ & $53,3 \%$ \\
\hline
\end{tabular}

Sumber: Data Penelitian, 2020

Teori ekonomi mengatakan bahwa perubahan harga untuk barang atau jasa yang ditawarkan oleh perusahaan akan memiliki efek padajumlah unit yang terjual. Dikatakan bahwa jika harga menurun, permintaan konsumen akan meningkat dan selanjutnya volume penjualan juga akan meningkat. Disisi lain jika harga meningkat, permintaan konsumen akan menurun yang akan menurunkan volumen penjualan. Harga dapat digunakan untuk bersaing dengan para pesaing dalam mendapatkan konsumen. Penelitian ini mencoba membuat pertanyaan kepada responden, apakah mereka menggunakan harga pokok produksi sebagai alat untuk meningkatkan volume penjualan mereka atau tidak dan jawabannya disajikan pada tabel 5 . Lebih dari $50 \%$ responden $(55,8 \%)$ tidak menggunakan harga pokok produksi untuk memenangkan persaingan, karena hanya $44,2 \%$ persen yang percaya dalam menggunakan harga pokok produksi yang bersaing atau penurunan harga jual dengan kompetitor mereka, namun perusahaan ekspor juga ditemukan menggunakan strategi ini dalam memenangkan persaingan daripada perusahaan non ekspor.

Tabel 6 juga menunjukkan alat keragaman dalam meningkatkan volume penjualan di media pada perusahaan berskala besar. Untuk perusahaan skala menengah, mereka lebih percaya pada iklan di media radio dalam meningkatkan volume penjualan mereka daripada iklan di media online. Perusahaan ekspor dan perusahaan non ekspor percaya dengan alat yang sama untuk meningkatkan volume penjualan mereka yaitu iklan di media radio dan iklan di media online. Responden percaya bahwa iklan produk mereka pada iklan di media radio dan iklan di media online akan menciptakan lebih banyak dampak dalam meningkatkan volume penjualan. 
Tabel 6. Alat untuk Meningkatkan Volume Penjualan

\begin{tabular}{|c|c|c|c|c|c|}
\hline \multirow[b]{2}{*}{ Deskripsi } & \multirow[b]{2}{*}{$\%$} & \multicolumn{2}{|c|}{ Skala Perusahaan } & \multicolumn{2}{|c|}{ Area Penjualan } \\
\hline & & Menengah & Besar & Ekspor & $\begin{array}{l}\text { Non } \\
\text { Ekspor }\end{array}$ \\
\hline Penurunan Harga Jual & $44,2 \%$ & $42,4 \%$ & $44,4 \%$ & $53,5 \%$ & $36,7 \%$ \\
\hline Iklan di Media Radio & $46,2 \%$ & $66,7 \%$ & $50,0 \%$ & $40,9 \%$ & $50,0 \%$ \\
\hline Iklan di Media Online & $63,2 \%$ & $63,6 \%$ & $55,6 \%$ & $56,5 \%$ & $70,0 \%$ \\
\hline Iklan di Media Televisi & $30,8 \%$ & $30,3 \%$ & $33,3 \%$ & $18,2 \%$ & $40,0 \%$ \\
\hline
\end{tabular}

Sumber: Data Penelitian, 2020

Tujuan utama dari peraturan, terutama peraturan pemerintah adalah untuk melindungi masyarakat, karyawan, lingkungan atau kelompok tertentu lainnya. Di Indonesia pemerintah pusat mengontrol harga listrik dan minyak untuk melind ungi masyarakat. Hotel juga dilakukan kontrol di Indonesia oleh pemerintah daerah untuk mengontrol tarif kamar hotel sehingga adil dan terjadi kompetisi yang sehat diantara mereka serta untuk melindungi konsumen.

Tabel 7. Dampak Regulasi

\begin{tabular}{|c|c|c|c|c|c|}
\hline \multirow[b]{2}{*}{ Deskripsi } & \multirow[b]{2}{*}{$\%$} & \multicolumn{2}{|c|}{ Skala Perusahaan } & \multicolumn{2}{|c|}{ Area Penjualan } \\
\hline & & Menengah & Besar & Ekspor & $\begin{array}{l}\text { Non } \\
\text { Ekspor }\end{array}$ \\
\hline Pemerintah Pusat & $40,4 \%$ & $35,7 \%$ & $40,8 \%$ & $45,5 \%$ & $45,5 \%$ \\
\hline Pemerintah Daerah & $51,9 \%$ & $54,6 \%$ & $23,1 \%$ & $36,3 \%$ & $56,7 \%$ \\
\hline
\end{tabular}

Sumber: Data Penelitian, 2020

Hasil penelitian pada Tabel 7 terkait dengan dampak regulasi menunjukkan bahwa regulasi pemerintah pusat lebih dipertimbangkan oleh perusahaan ekspor sebesar $45,5 \%$ terhadap penentuan harga pokok produksi. Akan tetapi peraturan pemerintah daerah lebih mempengaruhi perusahaan non ekspor terhadap penentuan harga pokok produksi mereka yaitu sebesar 56,7\% . Tabel 6 menjelaskan bahwa peraturan pemerintah pusat lebih berpengaruh terhadap penentuan harga pokok produksi pada perusahaan skala besar, akan tetapi peraturan pemerintah daerah lebih berpengaruh terhadap penentuan harga pokok produksi pada perusahaan skala menengah.

\section{SIMPULAN}

Penelitian ini menemukan bahwa perusahaan manufaktur di Provinsi Daerah Istimewa Yogyakarta memiliki lebih dari satu tujuan dalam menetapkan harga pokok produksi. Namun, tujuan utama dari penentuan harga pokok produksi untuk perusahaan skala besar adalah untuk mempertahankan pangsa pasar sedangkan untuk perusahaan skala menengah adalah untuk mencapai target profit mereka. Dapat dikatakan bahwa perusahaan-perusahaan skala menengah lebih ditekankan ke dalam tujuan jangka pendek. Sementara perusahaanperusahaan skala besar lebih terfokus kepada tujuan jangka panjang. Tujuan yang paling penting adalah bahwa faktor utama yang mempengaruhi harga pokok pokok produksi untuk semua sampel. Dalam perusahaan manufaktur, beban pokok penjualan diwakili biaya produksi untuk unit yang terjual yang terdiri atas bahan langsung, tenaga kerja langsung dan biaya overhead pabrik. Tidak ada perbedaan antara perusahaan skala besar dan perusahaan skala kecil 
untuk hal tersebut. Biaya juga merupakan faktor yang penting dalam mempengaruhi perubahan harga pokok produksi. Temuan lain adalah bahwa semua sampel percaya bahwa perubahan harga tidak akan efektif dalam meningkatkan volume penjualan. Adapun temuan pada penelitian ini juga memiliki beberapa keterbatasan. Keterbatasan tersebut yaitu terkait dengan sampel. Hal ini karena sampel hanya terdapat pada satu wilayah saja yaitu pada Provinsi Daerah Istimewa Yogyakarta, sehingga sampel dapat memiliki karakteristik yang sama sehingga akan mempengaruhi hasil penelitian ini.

\section{REFERENSI}

Anton, C. E., \& Costache, A. (2015). Transfer Pricing. Fiscal and Accounting Treatments. Bulletin of the Transilvania University of Brasov, 8(2), 253-260.

Aubert, F., Wang, J. J., \& Grudnitski, G. (2019). Convergence Consensus Analyst Earnings Estimates and Option Pricing in Modeling Material Accounting Misstatements. Review of Accounting and Finance, 18(1), 134-156. https://doi.org/10.1108/RAF-05-2017-0101

Bijakši, S., Marki, B., \& Bevanda, A. (2017). Expert Pricing System as Part of Marketing Mix. Informatologia, 50(3-4), 141-150.

Biondi, Y., \& Giannoccolo, P. (2015). Share Price Formation, Market Exuberance and Fnancial Stability Under Alternative Accounting Regimes. In Journal of Economic Interaction and Coordination (Vol. 10). https://doi.org/10.1007/s11403-014-0131-7

Desai, V., Xu, B., \& Zeng, T. (2016). Local Accounting Firms' Pricing Responses to Entry of The Big Four Accounting Firms into China. Journal of Accounting in Emerging Economies, 6(1), 50-68. https://doi.org/10.1108/jaee-06-2013-0030

Droste, N., \& Bartkowski, B. (2018). Ecosystem Service Valuation for National Accounting: A Reply to Obst, Hein and Edens (2016). Environmental and Resource Economics, 71(1), 205-215. https://doi.org/10.1007/s10640-0170146-3

Dugan, M. T., Turner, E. H., \& Wheatley, C. M. (2017). Pension Accounting Reform and Future Cash Flow Predictability. Journal of Financial Economic Policy, 9(1), 86-108. https://doi.org/10.1108/JFEP-05-2016-0032

Ghozali, I. (2016). Statistik Non-Parametrik: Teori dan Aplikasi dengan Program SPSS. In Universitas Diponegoro. https://doi.org/10.1002/14651858.CD002812

Hinrichs, U., Carpendale, S., Knudsen, S., \& Thudt, A. (2017). Analyzing qualitative data. Proceedings of the 2017 ACM International Conference on Interactive Surfaces and Spaces, ISS 2017. https://doi.org/10.1145/3132272.3135087

$\mathrm{Hu}$, Yan, \& Mao, C. (2017). Accounting Quality, Bank Monitoring, and Performance Pricing Loans. Review of Quantitative Finance and Accounting, 49(3), 569-597. https://doi.org/10.1007/s11156-016-0601-1

Hu, Yiming, Tian, X., \& Zhu, Z. (2016). Market Transaction Characteristics and Pricing Effect of Accounting Valuation Models. China Finance Review International, 6(1), 2-31. https://doi.org/10.1108/CFRI-05-2015-0036

Lee, S. H., Park, S., \& Kim, J. M. (2015). Suggestion for a Framework for a Sustainable Infrastructure Asset Management Manual in Korea. 
Sustainability (Switzerland), $\quad 7(11), \quad 15003-15028$. https://doi.org/10.3390/su71115003

Lin, P. (2019). Design and Implementation of Financial Accounting Information Management System of Shipping Companies Based on ERP. Journal of Coastal Research, 94(sp1), 470. https://doi.org/10.2112/si94-093.1

Luca, M. P., Ciocanea, B. C., \& Pitu, I. C. (2020). The Influence of Accountancy Data on the Transfer Pricing Policy in Romania. Series $V$ - Economic Sciences, 12(61)(2), 93-102. https://doi.org/10.31926/but.es.2019.12.61.2.12

Maxwell, J. A., \& Reybold, L. E. (2015). Qualitative Research. In International Encyclopedia of the Social $\mathcal{E}$ Behavioral Sciences: Second Edition. https://doi.org/10.1016/B978-0-08-097086-8.10558-6

McNabb, D. E. (2017). Fundamentals of Quantitative Research. In Research Methods for Public Administration and Nonprofit Management (Fourth edi, pp. 111-121). https://doi.org/10.4324/9781315181158-9

Merkusiwati, N. K. L. A., \& Damayanthi, I. G. A. E. (2020). Earnings Management and Different Tax Book To Explain Earnings Persistency. E-Jurnal Akuntansi, 30(1), 202. https://doi.org/10.24843/eja.2020.v30.i01.p15

Minakshi. (2017). Applications of Mathematics in Various Economic Fields. Research Journal of Science and Technology, 9(1), 175. https://doi.org/10.5958/2349-2988.2017.00029.8

Pohland, L., \& Kesgin, M. (2018). Pricing Determinants in Hotels: The Case of Luxury, Upscale, and Mid-Scale Price Segments. Journal of Revenue and Pricing Management, 17(4), 218-230. https://doi.org/10.1057/s41272-0170133-x

Pradnyadevi, M. A., \& Suardikha, I. M. S. (2020). Pengaruh Informasi Akuntansi dan Permintaan Investor terhadap Underpricing. E-Jurnal Akuntansi, 30(3), 746-759. https://doi.org/EJA.2020.v30.i03.p16

Setiawan, P. E., \& Putra, I. M. P. D. (2019). Keputusan Pemilihan Strategi Manajemen Laba Pada Perusahaan Yang Mengalami Financial Distress di Indonesia. Jurnal Ilmiah Akuntansi Dan Bisnis, 14(2), 196-207. https://doi.org/10.24843/jiab.2019.v14.i02.p05

Sugiyono. (2016). Metode Penelitian Kuantitatif, Kualitatif, dan R\&D. In cv Alfabeta.

Sunarni, C. W., \& Ambarriani, A. S. (2019). The Pricing Practices: Management Accounting Perspective. Review of Integrative Business and Economics Research, 8(2), 84-97. 